\title{
Marriage equality across the globe ${ }^{1}$
}

\section{The Netherlands (2001)}

The Netherlands was the first country to legally introduce marriage equality, with an overwhelming majority vote in Parliament of 107-33 in favour.

\section{Belgium (2003)}

Ninety-one Members of Parliament voted in favour of equal marriage, with only twenty-two votes against its introduction. Initially the new marriage bill excluded adoption rights for same-sex couples; this was adjusted in 2006.

\section{Spain (2005)}

On 30 June 2005, the Spanish Parliament voted to end all restrictions excluding same-sex couples from marriage, with a vote of 187 to 147 . The Spanish government under Prime Minister José Luis Rodíguez Zapatero simply added one line to existing legislation ensuring total equality with heterosexual unions: 'Marriage will have the same requirements and results when the two people entering into the contract are of the same sex or of different sexes.'

\section{Canada (2005)}

The Civil Marriage Act was first read in Canada's House of Commons on 1 February. The act redefined civil marriage with a gender-neutral definition as 'the lawful union of two persons to the exclusion of all others'. ${ }^{2}$ The act was passed in the House of Commons by a vote of 158-133 and was later cleared through Senate by a majority of 47 to 
21. The Civil Marriage Act came into effect with Royal Assent on 20 July 2005.

\section{South Africa (2006)}

In December 2005, a case was brought by the Lesbian and Gay Equality Project to the Constitutional Court of South Africa that the Marriage Act 'unconstitutionally excludes same-sex couples'. ${ }^{3}$ The court decided that this exclusion violated the constitutional rights of individuals and ordered Parliament to address the injustice within twelve months. In November 2006, by 230 votes to 41, Parliament voted in favour of amending the Constitution and introducing equal marriage.

\section{Norway (2009)}

On 27 June 2008, a new section under 'gender' was included in the Marriage Act, stating that 'two persons of opposite sex or of the same sex may contract marriage'. This amendment came into force on 1 January 2009 , ending discrimination against same-sex couples marrying. ${ }^{4}$

\section{Portugal (2010)}

A law was ratified by President Aníbal Cavaco Silva on 17 May 2010 extending marriage to same-sex couples. The original bill was introduced by Prime Minister José Sócrates in December 2009 and came into effect on 5 June 2010.

\section{Iceland (2010)}

The Parliament of Iceland voted unanimously to include the words 'man and man, woman and woman' to the country's marriage laws. The vote was forty-nine in favour, with no member of parliament voting against.

\section{Argentina (2010)}

Argentina became the first Latin American country to extend civil marriage to same-sex couples when the National Congress voted 33 to 27 in favour of the motion. President Cristina Fernández de Kirchner signed this into law on 21 July 2010.

\section{Denmark (2012)}

In 1989, Denmark became the first country to introduce civil partnerships for same-sex couples. It took the country until 15 June 2012 
to extend marriage to same-sex couples, with a vote of 85 to 24 in Parliament.

\section{Brazil (2013)}

Freedom to Marry describe the situation in Brazil as 'somewhat confusing,5 until 16 May 2013, when a National Justice Council decision ordered every state across Brazil to allow same-sex couples access to marriage.

\section{France (2013)}

A bill to introduce marriage for same-sex couples became law on 18 May 2013 after support from both houses of Parliament.

\section{Uruguay (2013)}

A law came into force on 5 August 2013, two days after President José Mujica signed a bill extending civil marriage to same-sex couples.

\section{New Zealand (2013)}

The marriage bill passed through Parliament on 17 April 2013 and came into effect on 19 August that year.

\section{England and Wales (2014)}

A law extending civil marriage to same-sex couples came into effect in England and Wales on 29 March 2014. The bill was debated numerous times in the House of Commons and in the House of Lords before receiving Royal Assent from Queen Elizabeth II on 17 July 2013.

\section{Scotland (2014)}

An overwhelming majority of Members of the Scottish Parliament voted in support of legalising marriage for same-sex couples. The law came into effect on 16 December 2014.

\section{Luxembourg (2015)}

In 2014, Luxembourg recognised a need to rewrite its antiquated marriage laws, which had not been subjected to major examination since 1804. The country's Prime Minister, Xavier Bettel, an openly gay man, put forward a bill to include full civil marriage equality. The bill was supported by Parliament by a vast majority of votes (56-4) 
in the Chamber of Deputies. Marriage equality came into force on 1 January $2015 .{ }^{6}$

\section{Ireland (2015)}

Marriage equality was passed by referendum vote of the people on 22 May 2015, signed into law by President Michael D. Higgins on 29 August and came into effect on 16 November 2015.

\section{Mexico - partial (2015)}

On 3 June 2015, the Supreme Court of Mexico ruled that judges must grant injunctions to allow same-sex couples to marry in all thirty-one Mexican states. Some states have introduced laws extending marriage to same-sex couples without the need for injunctions. However, there is still work to be done by Lesbian, Gay, Bisexual and Transgender (LGBT) organisations to ensure that same-sex couples can access marriage equally in all states.

\section{The United States (2015)}

On 26 June 2015, the Supreme Court ruled in favour of extending civil marriage to same-sex couples across all states of America.

\section{Greenland (2016)}

Members of Parliament in Greenland voted in favour of adopting Denmark's marriage law, thus extending marriage to same-sex couples from 1 April 2016.

\section{Columbia (2016)}

The highest court in Columbia, the Constitutional Court, ruled on 7 April 2016 to extend marriage to all. Marriage equality has been legal in Columbia since 28 April that year.

\section{Finland (2017)}

In December 2014, Parliament voted 105 to 92 to legalise marriage for same-sex couples, the law being signed for approval by President Sauli Niinistö. It did not come into effect until 1 March 2017.

\section{Faroe Islands (2017)}

On 1 July 2017, the Faroe Islands adopted the marriage law of Denmark, extending marriage to same-sex couples. 


\section{Malta (2017)}

Signed into law by President Coleiro Preca on 1 August 2017, marriage equality was legalised on 1 September the same year.

\section{Germany (2017)}

On 20 July 2017, President Steinmeier signed the marriage bill extending marriage to same-sex couples in Germany despite initial objections from Chancellor Angela Merkel. The bill became legal on 1 October 2017.

\section{Australia (2017)}

An unusual process was followed in Australia. Citizens took part in a postal vote on the issue of extending marriage to same-sex couples. The vote saw a 62 per cent majority in favour of extending marriage equality to same-sex couples but this was simply an opinion poll and had no legal basis through which the law could be changed. The positive response of the postal vote led the way for the Prime Minister Malcolm Turnbull to introduce a bill for a free vote in Parliament. The bill was passed and the law came into effect on 9 December 2017, with the first recorded marriage for a same-sex couple.

\section{Jersey (2018)}

Although a Crown dependency within the UK, Jersey only extended marriage to same-sex couples in 2018. A bill was passed on 1 February and signed with Royal Assent on 23 May 2018.

\section{Austria (2019)}

A Constitutional Court ruled that marriage would be legal for samesex couples from 1 January 2019.

\section{Taiwan (2019)}

On 24 May 2017, a Constitutional Court ruling concluded that same-sex couples should have the right to marry. The court ruled that laws should be enacted within two years of this date to extend civil marriage to same-sex couples. As on 21 February 2019 a draft bill was introduced which became legal on 24 May 2019.

\section{Costa Rica}

The issue of marriage for same-sex couples reached the Supreme Court in Costa Rica, and on 8 August 2018 it declared that laws 
prohibiting marriage for same-sex couples were unconstitutional. The court set a time period of eighteen months in which to enact laws extending civil marriage to same-sex couples. According to this ruling same-sex couples in Costa Rica will have access to marriage from 26 May 2020.

\section{Notes}

1 Details in this table supported by research from David Masci, Elizabeth Sciupac and Michael Lipka, Gay Marriage around the World, Washington, September 2014; and 'The Freedom to Marry Internationally', Freedom to Marry USA website, available at: www.freedomtomarry.org/pages/ the-freedom-to-marry-internationally (accessed 9 July 2018).

2 Mary C. Hurley, Bill C-38: The Civil Marriage Act Canada, Law and Government Division: 2 February 2005.

3 Lesbian and Gay Equality Project and Eighteen Others $v$ Minister of Home Affairs and Others, in the Constitutional Court of South Africa, Southern African Legal Information Institute, 1 December 2005.

4 Ministry of Children and Equality, Norway, The Marriage Act, ACT 1991-07-04 No. 47.

5 'The Freedom to Marry Internationally'.

6 'Luxembourg legislature votes to legalize same-sex marriage, adoption', LGBT Nation (18 June 2014). 